\title{
Light Work
}

National Cancer Institute

\section{Source}

National Cancer Institute. Light Work. NCI Thesaurus. Code C95545.

Work tasks that require little physical or mental effort. 